University of Wollongong

Research Online

Faculty of Social Sciences - Papers (Archive) Faculty of Arts, Social Sciences \& Humanities

2011

Neoliberalism and the biophysical environment 3: putting theory into

practice

Noel Castree

University of Wollongong, ncastree@uow.edu.au

Follow this and additional works at: https://ro.uow.edu.au/sspapers

Part of the Education Commons, and the Social and Behavioral Sciences Commons

Research Online is the open access institutional repository for the University of Wollongong. For further information contact the UOW Library: research-pubs@uow.edu.au 


\title{
Neoliberalism and the biophysical environment 3: putting theory into practice
}

\author{
Abstract \\ There now exists a significant body of theoretically informed empirical research into 'neoliberal \\ environments'. It comprises numerous studies which together explore the connections between neoliberal \\ principles and policies, on the one side, and the biophysical world on the other. However, making sense of \\ them is by no means straightforward, despite their common focus on neoliberal environments. It is \\ currently left to readers of these studies to synthesize them into a wider, joined-up account of neoliberal \\ environments. This and two companion articles aim for precisely this sort of broad and coherent \\ understanding. The contribution of this third instalment is twofold. First, I link the published empirical \\ studies to the theory proposed in the previous articles. Second, I then try to evaluate these studies \\ critically, since in the previous two contributions I have been implicitly supportive of the research \\ conducted so far. Intellectually honesty dictates that I show readers the other side of the argument.

\section{Keywords} \\ into, practice, putting, 3, theory, environment, biophysical, neoliberalism \\ Disciplines \\ Education | Social and Behavioral Sciences \\ Publication Details \\ Castree, N. (2011). Neoliberalism and the biophysical environment 3: putting theory into practice. \\ Geography Compass, 5 (1), 35-49.
}




\title{
Neoliberalism and the biophysical environment 3: Putting theory into practice
}

\begin{abstract}
There now exists a significant body of theoretically-informed empirical research into 'neoliberal environments'. It comprises numerous studies which together explore the connections between neoliberal principles and policies, on the one side, and the biophysical world on the other. However, making sense of them is by no means straightforward, despite their common focus on neoliberal environments. It is currently left to readers of these studies to synthesise them into a wider, joined-up account of neoliberal environments. This and two companion articles aim for precisely this sort of broad and coherent understanding. The contribution of this third instalment is two-fold. First, I link the published empirical studies to the theory proposed in the previous articles. Second, I then try to evaluate these studies critically, since in the previous two contributions I have been implicitly supportive of the research conducted so far. Intellectually honesty dictates that I show readers the other side of the argument.
\end{abstract}

Keywords: nature, neoliberalisation, path dependency, empirical analysis, evaluation

\section{Introduction}

This and two previous companion articles together aim to synthesise a body of new geographical research which explores the relationships between neoliberalism and the nonhuman world. This body of work is now sufficiently large that it is not easy to identify the 'signals in the noise'. The first article in my trio of contributions explained what 'neoliberalism' is and why it must be distinguished from processes of 'neoliberalistion'. The second article presented a theory of the relationship between neoliberalism and the biophysical world, using the political economic ideas of Karl Marx, Karl Polanyi and James O'Connor. All three theorists' work has been used in recent research by critical geographers intent on understanding the 'neoliberalisation of nature'. In this final piece I have two objectives. First, I want to put the theory developed in the previous article to work, and see how far the conceptual diagnosis of the neoliberalism-nature relationship illuminates the complex realities of nature's neoliberalisation in a vary of sites and settings. This exercise allows us to draw some general conclusions about the 'neoliberalisation of nature' to-date. Second, the article then departs from the otherwise constructive approach adopted, and - in the interests of offering a balanced account - enumerates some possible problems with the research literature that I have surveyed and synthesised in this and the previous two articles.

\section{Actually-existing neoliberalisms and the biophysical world: evidence- based analysis}


To what extent, and in what circumstances, have one or both of the two theoretical scenarios described at the end of the previous article been borne-out in practice? What has neoliberalisation done to the biophysical world and vice versa? Who has won and who has lost? And how, if at all, have the losers been able to fight back? The empirical studies conducted by geographers such as Karen Bakker, Kevin St. Martin, Scott Prudham, Erik Swyngedouw, James McCarthy, Becky Mansfield, Jessica Budds, Nik Heynen, Tad Mutersbaugh, Julie Guthman, Harold Perkins, Paul Robbins, Laila Smith, Morgan Robertson and Tom Perreault provide answers to these important questions. In presenting their research findings I will inevitably have to gloss important details. To make the discussion intelligible I relate specific studies to the seven dimensions of 'neoliberalism' presented in the first essay insofar as they are relevant to one or more of these dimensions. ${ }^{1} \mathrm{I}$ then, in the section entitled 'Empirical synthesis', try to make some sense of a potentially confusing picture. Throughout, the key thing to note is that the observed realities of nature's neoliberalisation are the focus, not the theoretical propositions thrown at readers in the latter part of the second article.

1. Privatization: In the biophysical domain, privatisation can entail the enclosure - for exclusive use or sale by individuals, communities or firms - of land, water, subterranean areas, the atmosphere or any components thereof (like a particular coral reef or a stand of rare trees). It can also, equally, involve representations of any of these things (as in a patent filed on the discovery of a specific animal gene). So, privatisation always represents a shift in social relations to the non-human world, changing rights of access, use and disposal of physical components of nature or certain representations of it (intellectual property). In short, previously communally owned, state-owned or unowned aspects of nature fall into private hands.

Critical geographers' research has, for the most part, focussed on physical rather than intellectual enclosure. Examples abound. Bakker's (2003) research into the post-1989 privatisation of water resource management in England and Wales shows how national state ('public') ownership has given way to control by a few large, private corporations with chief executive officers, shareholders and international investment portfolios. In his research into gold mining in Guyana, Bridge (2002) charts the enclosure of land by both small and medium

\footnotetext{
${ }^{1}$ As we will see, several of the studies yield insights that relate to several aspects of neoliberalism not just one. Since it would, however, be repetitious to cross-reference studies comprehensively, I inevitably do not inventory all of the ways separate studies speak to the several dimension of neoliberalism. The most obvious dimensions where virtually all the empirical studies are relevant are privatization and marketization, the two key pillars of neoliberalism.
} 
domestic investors, and large overseas investors, together purchasing prospecting and extraction rights from the national state. After the 1989 liberalization of mining laws, this poor and indebted country saw a fifteen fold increase in the area given over to mining permits or claims by 1994. The new 'owners' - who had purchased non-permanent rights to seek-out and mine gold - were a combination of domestic investors and large overseas mining firms. North of Guyana, in the United States, Robbins and Luginbuhl (2005) report that in California, Colorado, Nevada, New Mexico, Oklahoma, Oregon, Utah and Washington there has been a transfer of responsibility for wild game from states to (mostly) private landowners, such as farmers - according to their land acreage and the habitats involved. In research into north Pacific fisheries management, Becky Mansfield (2004a; 2004b; 2007) shows how American state bodies restricted access to fish stocks by distributing catch-quotas flexibly between fisherman's cooperatives, coastal communities and larger corporate fishing firms thus privatising a putatively 'open access resource'. Likewise - to take one final example Kevin St. Martin's (2005) study of fisheries enclosure in the US north east charts the new restrictions placed on designated boats in terms of allowable-catch and permitted fishing days/periods.

In these, and other cases to be highlighted below, it is clear that various environmentally-centred neoliberal policies have in some way greatly altered rights of access and use in a range of socio-economic settings. David Harvey (2003) has coined the term 'accumulation by dispossession' to describe this process - echoing Marx's concept of primitive accumulation. However, as we will see later in this section, not all the authors just mentioned see nature's enclosure as an act of robbery in the way that Harvey does notwithstanding their commitment to a Left-wing form of political economic analysis.

2. Marketization: In relation to the biophysical domain, marketization can entail two things, both of which involve the exchange of money between buyers and sellers, namely (i) the right of buyers to use some element of the non-human world in situ subject to sellers setting an affordable price; and (ii) the right of buyers to purchase, subject to price, some element of the non-human world abstracted from its biophysical context, as with a gold ring, Starbucks coffee or a fur coat. In a neoliberal society, marketization presupposes privatization (but not vice versa). In both theory and practice, it suggests that a stream of revenues is either created anew (where none existed before) or switched into private hands (where before states, the public or certain communities were beneficiaries) by virtue of pricing the goods and services provided by the non-human world. The flip-side of this is that monetarily 'free' access to certain biophysical phenomena is lost and/or paid access switches among different parties 
than was previously the case. As with privatisation, examples are not hard to seek in the empirical studies published by critical geographers.

Morgan Robertson's (2004) research into the commodification of wetlands in the US mid-west represents a striking case. Wetlands are complex ecosystems of varying size and composition: unique assemblages of water, vegetation, insects, animals and micro-organisms. Under federal law, wetland loss caused by land development must be 'mitigated'. One recent, favoured way for such mitigation to operate is by 'recreating' wetlands (lost to, say, a new housing development) elsewhere in the mid-west. Robertson shows how a new set of private commercial actors (so-called 'wetland bankers') have come into existence, their role being to take money off land developers in order to pay for the physical creation of new wetlands of a similar kind. This example of 'free market environmentalism', he shows, presumes not only that a suitable monetary price can be attached to the loss of important biophysical spaces; it also supposes the rough biophysical equivalence of the lost and the new wetlands, as if their uniqueness is fungible.

A similarly striking case is presented by James McCarthy, in his study of how large firms within the NAFTA region use the investor protections written into this Agreement. Where Robertson shows marketization to be an attempt to mitigate environmental harm, McCarthy tells a different story. In 1993 a US waste-disposal company Metaclad bought, and subsequently developed, an inactive toxic waste dump in the Mexican state of San Luis Potosi. The local government halted Metaclad's activities in 1995 on health and safety grounds. Metaclad subsequently began a proceeding against the Mexican government under Chapter 11 of NAFTA, citing the 'regulatory takings' concept which presumes that investors are entitled to earnings lost through the actions of others. In 2000 a NAFTA tribunal found in favour of Metaclad, ordering Mexico to pay $\$ 16.7$ million for outlays and lost revenue. McCarthy calls this the 'primitive accumulation of the conditions of production', because revenues are extracted from the biophysical world not through productive activities but, rather, by seeking compensation for not undertaking such activities. The right of firms to make money regardless of the human or environmental cost is, worryingly, taken as sacrosanct here, in McCarthy's view.

The already-mentioned studies by Bakker, Bridge and Robbins \& Luginbuhl also draw attention to nature's marketization, albeit in less dramatic ways. Bakker shows how private water firms have, on the whole, been able to make healthy profits by providing water and sewerage services to English and Welsh consumers. These consumers, meanwhile, have faced variable water pricing depending on where they live (within a general trend towards greater 
water costs); and in the early years of water privatisation many poor households faced cutoffs and very high bills as a proportion of their income. Bridge, in his Guyanese study, shows how an amendment to the 1989 Mining Act enabled far more land than previously to be purchased by wealthy domestic and overseas investors, at the expense of small domestic miners - though this held-out the promise of major mining projects, with attendant jobs, tax revenues etc. for Guyana's workers and government. Finally, Robbins \& Luginbuhl's study shows that newly entitled landowners charging a fee for the right of local or out-of-state parties to shoot elk and deer represents the private capture of previously public revenues. Likewise, attempts to create 'game farms' not only go against a long history in the US that wildlife is just that - wild; they additionally represent attempts to make wildlife pay for the benefit of a select group of ranchers and hunters. In both cases, Robbins \& Luginbuhl find little evidence that private wildlife managers are delivering effective animal and habitat husbandry as compared to a previous generation of state-officials.

3. State roll-back or deregulation: The withdrawal of the state as owner or manager of biophysical goods and services can occur for a number of reasons. One is what Bakker (2003) calls 'state failure', which is government's financial and administrative inability to deliver these goods and services at a price and standard that citizens deem acceptable. By the late 1980s, Bakker argues that the British state was simply unable to provide water and sewerage services affordably or effectively - the point being that such failure, in theory, could apply to any statecontrolled service that involves the biophysical world. Secondly, state bodies may be persuaded by the neoliberal argument that the most cost-effective and highest quality goods and services are delivered by private producers operating in competitive markets. Either way, the theme of state roll-back has been prominent in the geographical literature on the neoliberalization of nature.

A stark example of the consequences of this is provided by Prudham (2004) in his study of a serious water pollution incident in 2000 in Walkerton, Ontario. Six Walkerton citizens died and 2300 were infected as both e.coli and campylobacter bacteria got into the municipal water supply. In a complex argument, Prudham attributes this to an over-eagerness on the part of provincial government to (i) relinquish its regulatory roles in a climate of fiscal austerity, and (ii) 'free' business to operate with few regulatory restrictions. Conceding that both the weather conditions and human negligence had a role to play, Prudham nonetheless shows that neoliberal reforms greatly increased the risk of water contamination by farmers, making the Walkerton incident a 'normal accident'. 
In a similarly critical mode, Heynen and Perkins' study of tree cover in the famously 'green' city of Milwaukie also implicates the sub-national state. The city of Milwaukie has, over the last 25 years, suffered declining revenues because of fiscal retrenchment by state government and a shrinking local tax base resulting from economic contraction. Meanwhile, two outbreaks of Dutch elm disease led to a decline in the city's famously dense tree cover. Despite replanting efforts, Heynen and Perkins argue that the local state - operating in a neoliberal environment - is now unable to maintain the arboreal 'conditions of production' within the city. Operating with less revenue, having sold-off some local state land to private interests and denying itself the right to regulate tree growth on private land, the Milwaukie government - Heynen and Perkins argue - has left tree planting to the whim of disparate households, landlords and firms. Since most of Milwaukie's trees are now on non-public land, this situation threatens to radically reduce the city's tree cover in the medium-to-long term, with all this implies for quality of life, rainfall capture, temperate moderation, water run-off and the city's attractiveness to new residents and investors.

4. Market-friendly reregulation: State bodies operating in a neoliberal way will make the privatization and marketization of nature a reality wherever possible. This involves creating new laws and regulations; and ensuring that there are mechanisms to enforce these rules and procedures. In all the case studies cited above, state bodies have used their decision-making, legal and administrative powers to transfer ownership of the biophysical world and to attach monetary values to it. The national state still possesses the greatest range and intensity of these powers; but local state bodies are rarely insignificant, while many national states have ceded some of their authority to supra-national, quasi-state bodies like the WTO. Rather than rehearse already-mentioned studies again, let me revisit just two of them, and cite some additional ones, in order to make some wider points that recur throughout the published empirical literature.

In one of her several investigations of fisheries privatization, Mansfield (2004) examines the details of the 1998 American Fisheries Act (AFA) as it affected the Alaska pollock fishery - the world's largest single-species fishery, and of major economic and social importance to Alaskans. The AFA led to sweeping change in the organization of this 'openaccess' fishery, introducing a catch-quota system among a restricted group of relevant parties in order to prevent over-fishing on environmental and economic grounds. One of the shibboleths of neoliberals is that once state 'interference' is done away with, markets will 'spontaneously' take over. Against this, Mansfield shows the remarkable degree of state 
regulation required to make the pollock fishery privatized and marketized. The AFA had to be interpreted and enforced by the North Pacific Fishery Management Council, which involved exceedingly detailed and complex regulations being developed to: (i) negotiate fair relations between inshore fisherman, offshore fisherman, fish processors, commercial fishers, independent fishers, and indigenous (native American) communities; (ii) sort-out the AFA's relations to endangered species legislation (Pollock are eaten by the at-risk Stellar sea lion); and (iii) also sort-out how pollock fishery rules would impact on other Alaskan fisheries, such as crab. In short, Mansfield shows that the neoliberalization of the pollock fishery involved as much (if not more) state regulation than previously. The conclusion appears paradoxical - 'the market' is both created and regulated by the state. It suggests that, in Mansfield's view, neoliberalisation is not about the state 'stepping-aside' but, rather, the state changing its role to actively ensure markets 'work' where they might otherwise founder. (A similarly convincing case here is provided by Bakker, 2003).

If the 'minimal state' is a seen by the likes of Mansfield (and Bakker) to be a myth when it comes to nature's neoliberalisation, so too is the neoliberal idea that states are (or ought to be) 'neutral' in relation to markets once they are established. It is a truism among theorists of the capitalist state that it must both work 'inside' and 'outside' the economy simultaneously, somehow negotiating the interests of business, workers, the public, and myriad special interests. This can produce dilemmas for state institutions, as well as situations where upholding certain interests involves ignoring or challenging others. Bridge's study of Guyana is one example of how dilemmas can be negotiated. Gold mining in the country has historically been dominated by small and medium domestic operators. An early 90s amendment to national mining legislation was designed to encourage large overseas investors to enter the Guyanese gold industry. But the amendment was also designed so that overseas interests had to have domestic partners, a way of trying to make external investment pay dividends for certain Guyanese nationals. A recent study by Prudham and Morris (2006) suggests that neoliberal state bodies are not always so adept at brokering different interests. Prudham and Morris (2006) scrutinize a national review of GM (genetically-modified) foods regulation by the Canadian Biotechnology Advisory Committee (CBAC) between 1999-04. GM foods have, of course, been heavily criticized on environmental and health grounds by the likes of Greenpeace and Britain's Soil Association. Prudham and Morris show that, from the start, the CBAC - a supposedly impartial expert body advising the Canadian government - was already committed to creating a market for GM foods and spent a good deal of its energy trying, subtly, to persuade the Canadian public that this was a good thing. Echoing this 
conclusion in reverse, Hollander's (2004) study of commercial sugar growing in south Florida shows American politicians and bureaucrats flatly contradicting their own commitment to 'free trade' by protecting US sugar producers against more competitive overseas rivals.

5. Use of market proxies in the residual governmental sector: In relation to the nonhuman world or society, the use of market proxies entails making remaining state-run activities as economically efficient as is possible. 'Efficiency' here means that, whether delivering goods and services to citizens or acting as a regulator, state institutions operate as if they were private sector firms subject to a competitive environment. Where 'artificial' competition cannot be created among state institutions for practical reasons, other measures can be used, like rules insisting on full cost-recovery, balanced budgets and high-standards of service provision.

In the biophysical domain, one service area where even many neoliberal states find it difficult to 'let go' relates to 'basic' natural resources like water and oil - resources that are either universally required by all citizens or which have strategic importance for a given country. Laila Smith's (2004) study of water provision in Cape Town in a case-in-point. In an empirically rich article, Smith shows how the Cape Town government introduced waterdemand management (through metering and pricing), the outsourcing of some water services as a cost recovery strategy, and water cutoffs for non-paying citizens. One result, Smith argues, is that 'economic efficiency' has won-out over social equity concerns since the burden of water bills and cut-offs has fallen on Cape Town's poorest residents - those least able to pay for what many regard as a human right, not something to be consumed according to income. Since this has occurred in a post-apartheid environment overseen by a mostly nonwhite party (the ANC) supposedly attuned to racialized injustice, it threatens to erode the legitimacy of Cape Town's governing party.

6. The strong encouragement of 'flanking mechanisms' in civil society: As noted earlier, the non-human world provides a wide array of valued things to individuals, communities, social groups and citizens - this world 'matters'. Where neoliberal state bodies do not (or no longer) guarantee access to, or the upkeep of, specific biophysical landscapes and resources, they often encourage civil society actors to fill the vacuum - be they NSMs, charitable organizations, NGOs or community organizations. These actors may receive some state funding and may be empowered to discharge duties and functions heretofore provide by state institutions. The key thing is that the must accept the 'neoliberal settlement' rather than seek to challenge it from within. 
Heynen and Perkin's (2005) already mentioned study suggests that without requisite funds and armed only with the power of persuasion, such actors may do little to offset the negative aspects of nature's neoliberalisation. 'Greening Milwaukie' - a not-for-profit, quasiprivate institution - is now the city's main agent for tree planting. Heynen and Perkin's suggest that it lacks sufficient ability to make householders and landlords plant on their land, and is likely to be especially ineffective at greening low income neigbourhoods where landlordism typically prevails. In a rather different case, Holifield (2004) examines how socalled 'environmental injustice communities' (EJCs) were, during the Clinton years, brought into the practices of the Environmental Protection Agency (EPA). In neoliberal terms, EJCs are those communities suffering the ecological 'externalities' of economic activity: they are victims of 'market failure' (such as toxic waste being dumped nearby without the EJC in question gaining financial compensation or the offending firm/s having to pay clean-up costs). Holifield shows how, under Clinton, EJCs - whose politics over the last 30 years have typically been radical-left, linked as they are with the civil rights movement of the 1960s were given much more visibility within the EPA's remit to remediate toxic sites. Though EJCs are not, Holifield argues, products of neoliberalism, they have been brought within its logics of property and payment by the EPA. This contrasts with a previous situation where EJCs were typically ignored by state officials unless they fought hard and loud enough to get their grievances heard.

7. The creation of 'self-sufficient' individuals and communities: Neoliberalism, again in respect of the biophysical world, aims to decollectivise social relationships to that world. The emphasis is on the 'liberal' in neoliberal: that is, people's supposed freedom to choose how, why and to what ends they relate to nature locally and beyond. Since such freedom is scarcely that if it is constrained by people's membership of regulated social groups (e.g. religious or ethnic ones), then neoliberals see individuals and small-scale communities as the proper locus of neoliberal subjectivity. The published geographical literature contains a range of examples of such atomized subjecthood both failing to take hold and succeeding. The successes, predictably enough, relate to all those private firms and investors already disposed to see themselves as sovereign prior to being given the chance to privatize and marketize new aspects or spaces of nature. One example is provided by Wolford (2005), in her study of Brazil's now-famous Movement of Landless Workers (MST). Agrarian land has been very unevenly distributed in Brazil, as in the rest of Latin American, for several generations. As part of a wider package of neoliberal measures, President Cardoso rolled-out a Market-Led Agrarian Reform (MLAR) programme between 1997 and 2003. In theory this provided MST 
members with a chance to secure land on the basis that they were not only entitled to it (many were former employees of large landowners who had worked the land), but that they would make it productive too. However, Wolford shows that the MLAR generally favoured existing large landowners, not the aspirant smallholders of the MST (see also Wolford, 2007).

However, not all cases of nature's neoliberalization have favoured corporate 'individuals' over-against other notionally 'free' actors. In her most recent article, Mansfield (2007) looks at the Western Alaska Community Development Quota (CDQ), which gives a portion of fisheries income to poor, mostly native Americans living in the region. Though these residents constitute a numerically small, relatively distinct 'community', Mansfield suggests that they are not identifiably 'neoliberal' in the way the CDQ imagines them. Instead, the CDQ is a redistributive, state-dictated policy intended to assist native Americans who have suffered generations of hardship at the hands of colonists from the US mainland. It identifies this disadvantaged group as a victim of historic injustice as much as a notionally self-governing collective of like-individuals.

In a related vein, James McCarthy (2006) has undertaken a study of 'community forestry' in the US and Canada since the early 1990s. As with EJCs, community forests precede neoliberalism and are in no obvious sense a product of it. They entail local communities managing nearby forest areas as against state or private owners/managers. However, they have the capacity to be articulated with neoliberal ideas of economic selfmanagement. One of McCarthy's examples here is British Columbia, which instituted a Community Forests Pilot scheme in 1998, making it a permanent part of forestry management in 2003. The Pilot was instituted within a wider neoliberal policy environment prevalent in British Columbia through the 1990s. Though 99\% of available timber resources in the province are leased to forest-products corporations, $1 \%$ are now controlled by various communities who are able to earn revenue from logging or other activities. This contrasts with the prevailing corporate model, where revenue often leaves profitable localities, to be pocketed by distant shareholders or spent elsewhere in a firm's production network.

In contrast to these (not always obvious) examples of 'success', the research literature also contains instances of failure, where individuals and communities do not recognize the call to accept the logics of neoliberalism as a fait accompli. Holifield's study provides a mild example, showing that EPA officials were sometimes unable to govern the conduct of EJCs within their own procedures for recognizing and compensating such communities. Given their civil rights, often militant heritage, some EJCs spoke in a collectivist, non-market language that evoked a moral economy peppered with powerful terms like 'racism', 
'inequality' and 'injustice'. More dramatically, Perreault's $(2005,2006)$ account of the socalled 'water and gas wars' in Bolivia (2000 \& 2003 respectively) show how neoliberal policies of environmental governance went against prevailing norms and values within the population: a case of 'market economy' absent a 'market society'. The privatization of water services and the opening of gas reserves to overseas conglomerates generated widespread and often violent protest, protest that ultimately toppled the Sanchez de Lozada government and paved the way for Morales' current left-wing, populist regime.

\section{Empirical synthesis}

What have we learnt from this survey of the empirical literature? Unsurprisingly, elements of both the theoretical scenarios depicted in article two are evident in the studies. But can we go beyond this rather banal observation to identify some commonalities in otherwise discrete studies of nature's neoliberalisation? I think we can. My interpretation of the literature yields the following conclusions:

1. There is an often large gap between neoliberal theory and practice: the neoliberalisation of nature rarely proceeds without strong state intervention, forms of protest, or various 'externalities' that 'the market' and 'flanking organisations' are unable adequately to deal with (e.g. Mansfield, 2004; Heynen \& Perkins, 2005; Perreault, 2006).

2. Nature's neoliberalisation often encounters social barriers: the failure to create a truly 'market society' means that neoliberal policies can encounter moral economies that sometimes place limits on the commodification of nature (e.g. Perreault, 2006).

3. Nature's neoliberalisation often faces biophysical obstacles: Robertson's (2004; 2007) studies show that attaching a price to nature is often highly problematic, while Robbins \& Luginbuhl's (2005) study shows that game farming creating unanticipated diseases which have called its commercial viability into question.

4. Nature's neoliberalisation must be highly tailored to local social and biophysical circumstances in order to work: this conclusion follows from 2 and 3. Among other examples, the protests in Bolivia noted by Perreault (2006) contrast starkly with the acceptance of fisheries privatisation in the Alaska region (Mansfield, 2004) suggesting that neoliberalism only 'works' if it is properly adapted to different contexts.

5. Nature's neoliberalisation tends to disadvantage the poor and the wider public: this insight is evident in Bakker's (2003) work, Mutersbaugh's (2005, 2003) studies of 
small Mexican farmers, Budd's (2007) study of Chilean peasant irrigators, Prudham's (2004) Walkerton study, McCarthy's (2004) analysis of regulatory takings, Smith's (2004) Cape Town study, Heynen's (2006) sole-authored Milwaukie study, and several others besides. And where neoliberal policies appear to offer openings for the socially disadvantaged - as in Wolford's (2005) Brazil study - there is evidence that these openings are more apparent than real.

6. Nature's neoliberalisation can have positive environmental and social outcomes: in contrast to the previous point, there is evidence that nature's neoliberalisation does not always and only benefit political-economic elites. Bakker's (2003) study shows that private firms have delivered improved water quality since 1989 in England and Wales; Robertson's (2004) suggests that, while 'real' and 'created' wetlands may not be quite the same, neoliberal policies do at least permit the latter to in some sense compensate for the loss of the former; and Mansfield (2007) and McCarthy (2006) together show that neoliberalism is not always antithetical to social justice and community empowerment agendas. All this said, the weight of evidence suggests that point 5 overshadows 6. Guthman's (2007) study of voluntary food labels as a means of creating a market in 'ethical' goods encapsulates the asymmetry. She concedes that these labels allow some farmers and consumers to create an ethical food market, but she argues that this market is limited and socially exclusionary.

7. Nature's neoliberalisation has not been successfully resisted by those who dispute it: despite point 5 , the studies surveyed here present little evidence to suggest that those who suffer because of nature's neoliberalisation have been able to halt its progress. Despite Perreault's $(2005,2006)$ research, this is clear in many of the studies reported above.

8. The process and outcomes of nature's neoliberalisation are geographically constituted: this point follows from all of the previous ones. The studies surveyed suggest not just that nature's neoliberalisation is geographically variable; rather, they suggest that it is geographically constituted - something that is moulded all-the-way-down by the socio-physical settings in which neoliberal policies are applied.

9. The theoretical insights of Marx, Polanyi and O'Connor are analytically useful: as noted earlier, most of the researchers whose work I have reviewed use one or more of these three authors' insights. Concepts like 'primitive accumulation', 'capital accumulation', 'conditions of production', 'pseudo-commodities', 'double movement' and so on, provide powerful framing devices that have helped diverse critical 
geographers make sense of a range of erstwhile different cases of nature's neoliberalisation. The fact the neoliberalism has not yet been undone by the contradictions identified by Marx, Polanyi and O’Connor does not necessarily invalidate these author's insights. Instead, it has pointed empirical researchers to the reasons why these contradictions are contained or somehow managed in diverse situations and settings.

\section{Evaluation: what's wrong with geographical research into nature's neoliberalization?}

In the previous section I reviewed the geographic literature on neoliberalism and nature in good faith. I took it for granted that the insights of the various empirical studies discussed are factually accurate: that is, I assumed that they describe objectively sets of processes and outcomes in different parts of the world. I similarly assumed that they provide a test-bed for the epistemic claims of theoretical arguments presented in the first article. And I also did not question the way the research was conducted, nor the quality of the evidence and insights adduced. In this final section of the article, I want to change tack and move from being a sympathetic reviewer (my stance so far) to being a critical reviewer. I switch positions simply in order to provide some balance to the discussion: readers of this article ought to be able to question the material surveyed rather than be obliged to take it at face-value. I will make a series of points in which the criticisms become progressively more fundamental.

Has the empirical research reviewed here given us an adequate understanding of nature's neoliberalisation? There are good reasons to say 'no'. Despite the rigour of many of the studies discussed above, some common problems are arguably evident in the published literature. The first is that it is small relative to the topic at hand. The neoliberalisation of nature is a worldwide process, taking us from the planetary scale (e.g. the market-based Kyoto Protocol on greenhouse gas emissions) to the local scale (i.e. numerous specific initiatives like those investigated by Bakker, Mansfield and others). The handful of geographical studies undertaken to-date cannot, arguably, give us more than a partial insight into such a large and varied phenomena. At best, they offer us a first approximation - a preliminary sense of which of the two theoretical scenarios depicted earlier is coming to pass in reality, where and why. Second, questions can be asked about the quality and selectivity of evidence presented. To hazard a generalisation, most of the empirical literature I have surveyed is presented in a very 'qualitative style'. That is, much of the literature takes the form of 'stories', peppered with figures, graphs, numbers and quotations. What is usually unclear is how the evidence was 
gathered methodologically, how much of it was analysed relative to the sum-total of available evidence, and how comprehensive data presentation is compared to the sum-total of data analysed. Some readers of the literature might suspect that evidence is being cherry-picked to tell a pre-determined story, rather than being used to complicate or even challenge that story. Thirdly, this links to a division in the published literature between studies that are 'research papers' and those that are not. The two should not be confused, even though they may appear in the same peer-review academic journals or edited books. Good examples are provided by Bakker (2005) and St. Martin (2005). Bakker's article on water commodification is amply evidenced and closely argued. St. Martin's essay - which suggests that neoliberal approaches to fisheries management overlook the importance of community cooperation among fishermen - is more of a thought-piece. It makes interesting claims that it does not really evidence. Unwary readers beware!

Fourth, most of the studies discussed in section IV are not comprehensive: they deploy narrow rather than wide-angled lenses. An example is Hollander's (2004) Florida study, which does not discuss the positive employment implications for 'third world' sugar producers should US protectionism give way to free trade policies. By focussing on how Florida sugar producers can defend their livelihoods, she casts the other side of the coin into darkness. Fifthly, and relatedly, much of the critical geographic literature on nature's neoliberalisation ignores important counter-factual questions. Such questions oblige analysts to consider what would or could have happened if things had been otherwise. An example is Heynen and Perkin's Milwaukie study, which sidesteps the important topic of whether the Milwaukie government had non-neoliberal options through the 1990s. Could it really have managed its trees differently than it did, given the fiscal squeeze it undoubtedly faced? Were more socially progressive and ecologically beneficial alternatives realistic and available?

In the sixth place, there is an emphasis in the literature on analysis over policy prescription. Analysis is, of course, of critical importance: it helps us address the classic research questions of 'what?', 'why?' and 'how?'. But policy prescription in the widest sense of that term is vitally important too - I say 'widest' because I do not only mean policy in the conventional sense of government policy. Considered broadly, policy prescription involves analysts looking at what real world actors ought realistically to do (or have done) in order to achieve their agendas, to alter their reality, to challenge rival interests, and so on. Without policy prescription analysis can leave us enlightened but impotent: unable to see what changemaking measures should take place. The geographers whose work I have reviewed are 'critical' - political economists sympathetic to the plight of the poor, broadly in favour of 
wealth redistribution to this class of people, and champions of 'sustainable development'. Given this, it is arguably surprising that so few of them have ventured to answer V. I. Lenin's classic political question, 'what is to be done?'. In the absence of policy prescription, their analyses can (admittedly uncharitably) be read as mute complaints about a neoliberal world that they do not like but are unable to help change.

A final (and more fundamental) criticism builds on arguments made by British geographer Clive Barnett (2008). In a new article entitled 'What's wrong with neoliberalism?', Barnett suggests that some critical geographers may be conflating fiction with fact - they may be guilty of what philosopher Roy Bhaskar (1989) has called the 'epistemic fallacy', where one mistakes one's ideas about the world for what the world is actually like. I noted earlier that neoliberalism is very much a critics' term, one specific to a transnational group of leftists that includes the geographers whose work I have reviewed in this article. Barnett asks why these geographers - given their avowed commitment to the study of complexity, unevenness and path-dependency - persist in naming certain situations 'neoliberal'. After all, he argues, if Larner, Peck and Ong are right that 'neoliberalism' never exists in a pure form, then its impure forms cannot, by definition, be described and criticised as neoliberal. His answer is that critical geographers have been seduced by a simplistic, highly moralistic worldview that ranges solidarity, the welfare state and social justice for the poor (all coded positive) against markets, individualism and private property (all coded negative). This implausibly simplistic worldview, Barnett argues, silently underwrites numerous geographical case studies of neoliberalization and so binds the authors of these studies into an epistemic-political community of the likeminded (see also Barnett, 2005).

Barnett's argument calls to mind the famous concept of a 'paradigm', popularised by historian of science Thomas Kuhn (1962). Groups of researchers who share the same paradigm, Kuhn argued, utilise a common suite of fundamental concepts in their analyses and share the same set of assumptions about the nature of reality. Since these concepts and assumptions are more-or-less sacrosanct, researchers within a paradigm spend most of their energy doing 'normal science' - that is, routine research in which the paradigm is used to make sense of hitherto unknown aspects of reality. This raises the question of whether empirical research is merely conditioned by a paradigm - meaning that reality might throw-up surprises that challenge paradigmatic concepts and assumptions - or whether it is paradigm determined. If the latter applies then we confront the possibility that research constructs its objects, while purporting to analyse their true nature. 
Barnett may well be right that geographical research into various neoliberalizations is too ensnared in unwritten beliefs to let the evidence 'do the talking'. Yet, despite having some sympathy for his view (Castree, 2005; 2006), I am not sure Barnett's criticism is entirely fair. Certainly, some of those researching nature's neoliberalization have sought to rebuff his charge, directly or otherwise. Three counter-arguments stand-out. The first comes from James McCarthy (2006). McCarthy does not deny that neoliberalization is hybrid, variegated and contingent process within and between different contexts. However, he also argues that "Recognition of such complexity ... makes ... identifying the neoliberal component of particular empirical ensembles quite difficult: neoliberalism clearly does not exist as a Platonic ideal only imperfectly realized in actual circumstances, but, absent such a standard, it is not clear how analysts recognize neoliberalism when they see aspects of it in hybrid form” (p. 87). This is a robust point: McCarthy is arguing that analysts must approach empirical analysis with some (perhaps overly) coherent abstractions in their minds, otherwise they would be cognitively blind. It is entirely a matter of the researcher's skill whether - pace Barnett - these abstractions then impose themselves onto the analysis rather than guide (and stand to be modified by) it.

A second counter-argument to Barnett's can be extracted from Mansfield's (2004; 2007) several fisheries studies. Mansfield's research is arguably a model example of how to investigate neoliberalization as a hybrid process involving more-than-neoliberal elements. Where Barnett detects the surreptitious imposition of a binary worldview by neoliberalism's critics, Mansfield's research shows precisely why neoliberal policies could not work in pure form and survive the process. The particular histories and geographies of Alaskan fisheries communities meant that the American Fisheries Act and its interpretation by the North Pacific Fishery Management Council had to temper 'strong' neoliberal policies from the getgo. In a sense, and even though she still uses the term 'neoliberalism' to frame her analysis, Mansfield's work shows that the double movement against neoliberalism was factored into Alaskan fisheries policy as part of its very character.

Finally, it is important to note that the very best geographical research into nature's neoliberalization achieves a high level of analytical and normative sophistication. Bakker's $(2003,2005)$ research is exemplary here. Far from reducing the empirical details of her case studies to underlying and simplistic theoretical-moral precepts, she has shown consistently that the details matter immensely in water privatization projects. Her dissection of water ownership and pricing into numerous, different, actually-existing forms leads her to argue that 'neoliberalism' has divergent modes of operation and outcomes depending on the property 
and pricing arrangements. This echoes Peck's point that 'neoliberalism' is itself diverse - and to be evaluated accordingly - even prior to its articulation with non-neoliberal practices and policies. Bakker's work thus shows that empirical studies of neoliberalism can render implausible the sort of simplistic worldview that Barnett suggests underlies these self-same studies.

\section{Conclusion}

This article and its two predecessors have reviewed theoretically-informed, empirical research by critical geographers scrutinizing the 'neoliberalization of nature'. The three pieces have, I hope, performed several useful functions, both for those unfamiliar with this research and those who have wondered how, if at all, its component parts fit together into some larger whole. I have presented a joined-up theoretical account of nature's neoliberalization as a way of conceptually-framing and positioning otherwise separate empirical studies. I have sought to map these studies in relation to neoliberalism's several dimensions, in the process (I hope) demonstrating that neoliberalism is a profoundly biophysical project rather than incidentally so - both at the levels of theory and actuality. I have also sought to distil some general lessons from the empirical research - some signals in the noise. Finally, despite my strong identification with the work of the authors reviewed, I have ended this final article on a critical note, encouraging readers to question rather than defer to the geographical literature on nature's neoliberalization. For its practitioners, doing academic research is a time consuming and demanding process. But reading, and making sense of, the published literature is an equally challenging task for teachers and students. I hope that the three articles, despite their combined length, have rendered the challenge less forbidding for those interested in the why and wherefore of nature's neoliberalization. ${ }^{2}$

Acknowledgements: With respect to all three articles (not just this one) my thanks to Gary Brierley, Basil Gomez and Geoff Wilson for their sympathetic editing and two anonymous referees for their very useful comments, even though - in one case - I felt unable to follow the advice offered. I did not intend or want to publish three Compass essays on this topic but this is how it has worked out, and I only hope readers have had the fortitude to stay-the-course. I am very grateful to the editors for giving me the chance to write as such length in the journal.

2Students and teachers who want to read into the literature surveyed should begin with Heynen et al.'s (2007) book and then the two special issues of Geoforum (2004) and Capitalism, Nature, Socialism (2005) from which this book draws. A more expansive and up-to-date exploration of the literature can be found in Castree (2011). 


\section{Bibliography}

Bakker, K. (2003) An uncooperative commodity (Oxford: Oxford University Press).

Bakker, K. (2005) 'Neoliberalizing nature? Market environmentalism in water supply in England and Wales', Annals of the Association of American Geographers 95, 3: 542-65.

Barnett, C. (2008) 'What's wrong with neoliberalism', In S. Smith et al. (eds) Handbook of social geography (London: Sage), pp. 213-31.

Bhaskar, R. (1989) Reclaiming reality (London: Verso).

Bridge, G. (2002) 'Grounding globalization’, Economic Geography 78, 3: 361-86.

Budds, J. (2007) 'The 1981 Water Code', in W. Alexander (ed.) 'Lost in transition' in Chile (Lanham: Lexington Books), in press.

Castree, N. (2005) 'The epistemology of particulars: human geography, case studies and 'context'. Geoforum 36, 5: 541-44.

Castree, N. (2006) 'From neoliberalism to neoliberalisation: consolations, confusions and necessary illusions', Environment and Planning A 38, 1: 1-6.

Castree, N. (2011) 'Neoliberalism and the biophysical environment: a synthesis and evaluation of the research', Environment \& Society volume 2, forthcoming.

Guthman, J. (2007) 'The Polanyian way?', Antipode 39, 3:456-78.

Harvey, D. (2003) The new imperialism (Oxford: Oxford University Press).

Heynen, N. (2006) 'Green urban political ecologies', Environment and Planning A 38, 3: 499-516. Heynen, N. and Perkins, H. (2005) 'Scalar dialectics in green: urban private property and the contradictions of the neoliberalization of nature', Capitalism, Nature, Socialism 16, 1: 5- 18. Holified, R. (2004) 'Neoliberalism and environmental justice in the US Environmental Protection Agency', Geoforum 35, 3: 285-98.

Hollander, G. (2004) 'Agricultural trade liberalization, multifunctionality and sugar in the south Florida landscape', Geoforum 35, 3: 299-312.

Jessop, B. (2002) The future of the capitalist state (Cambridge: Polity).

Kuhn, T. (1962) The structure of scientific revolutions (Chicago: Chicago University Press).

Mansfield, B. (2004a) 'Rules of privatization: contradictions in neoliberal regulation of North Pacific fisheries' Annals of the Association of American Geographers 94, 3: 565-84.

Mansfield, B. (2004b) 'Neoliberalism in the oceans: "rationalization," property rights, and the commons question', Geoforum 35(3): 313-326.

Mansfield, B. (2007) 'Property, markets and dispossession', Antipode 39, 3: 479-99.

Marx, K. (1867 [1990]) Capital, volume 1. Trans. B. Fowkes. (Penguin: Harmondsworth). 
McCarthy, J. (2004) 'Privatizing conditions of production: trade agreements as neoliberal environmental governance', Geoforum 35, 3: 327-42.

McCarthy, J. (2006) 'Neoliberalism and the politics of alternatives', Annals of the Association of American Geographers 96, 1: 84-104.

Mutersbaugh T. (2005) 'Fighting standards with standards: harmonization, rents, and social accountability in certified agrofood networks', Environment and Planning A 37, 11: 2033-2051 Mutersbaugh T, (2003) 'Ethical trade and certified organic coffee: the implications of agricultural product certification for Mexican producer households and villages', Transnational Law and Contemporary Problems 12, 1: 89-107.

Perreault, T. (2005) 'State restructuring and the scale politics of rural water governance in Bolivia', Environment and Planning A 37, 2: 263-84.

Perreault, T. (2006) 'From guerra del agua to guerra del gas', Antipode, 38, 1: 150-72.

Prudham, S. (2004) 'Poisoning the well: neoliberalism and the contamination of municipal water in Walkerton, Ontario', Geoforum 35, 3: 343-60.

Prudham, S. \& Morris, A. (2006) 'Making the market "safe" for GM foods', Studies in Political Economy 78, Autumn: 145-75.

Robbins, P. \& Luginbuhl, A. (2005) 'The last enclosure', Capitalism, Nature, Socialism 16, 1: 4561.

Robertson, M. (2000) 'No net loss', Antipode 32, 4: 463-93.

Robertson, M. (2004) 'The neoliberalization of ecosystem services', Geoforum 35, 3: 361-74.

Robertson, M. (2007) 'Discovering price in all the wrong places', Antipode 39, 3: 500-26.

Smith, L. (2004) 'The murky waters of the second wave of neoliberalism', Geoforum 35, 3: 37593.

St. Martin, K. (2005) 'Disrupting enclosures in New England fisheries', Capitalism, Nature, Socialism 16, 1: 63-80.

Wolford, W. (2005) 'Agrarian moral economies and neoliberalism in Brazil', Environment and Planning A 37, 2: 241-62.

Wolford, W. (2007) 'Land reform in the time of neoliberalism', Antipode 39, 3: 550-70. 